\title{
Sexual Maturity of Crocidura russula (Insectivora: Soricidae)
}

\author{
Françoise JEANMAIRE-BESANÇON ${ }^{1}$
}

\begin{abstract}
Jeanmaire-Besançon F., 1988: Sexual maturity of Crocidura russula (Insectivora: Soricidae). Acta theriol., 33, 35: 477-485. [With 3 Tables \& 3 Figs].

Crocidura russula $(\mathrm{n}=537)$ were captured in western Switzerland between 1977-1980. Histological study of sexual organs and tooth wear analysis were used to estimate the age of sexual maturity. $35 \%$ of the individuals reproduced in the year of their birth, the females being more precocious $(\mathbf{4 3 . 6 \%})$ than males $(\mathbf{2 8 . 6 \%} \%)$. Juveniles born in the spring attain their sexual maturity earlier than those born later, in summer or autumn. Overwintered individuals start to reproduce in spring. In July, most reproductive individuals were the young of the year. This precocious maturity of Crocidura russula can be explained by the palaeotropical origin of Crocidurinae.
\end{abstract}

[Institut de Zoologie et d'Ecologie animale, Université de Lausanne, $\mathrm{CH}-1015$ Lausanne, Suisse]

\section{INTRODUCTION}

Reproduction in a species depends, among other things, on climatic and palaeohistorical factors. In particular, the members of the two subfamilies of Soricidae (Crocidurinae and Soricinae) differ in their reproduction strategies, as a result of their evolution in two different climatic regions (Vogel, 1980). This is especially true for the age of sexual maturity, one of the important components of reproduction strategy. The Soricinae, which have a holarctic distribution, usually mature the year following their birth. However, some cases of precocious maturity are reported, for example, in Neomys fodiens (Bazan, 1956), Sorex arcticus (Schwarz, 1959), Sorex araneus (Stein, 1961) and Sorex daphaenodon (Schwarz, 1962). On the other hand, data from breeding colonies and field caught tropical members of the Crocidurinae, a subfamily of palaeotropical origin, suggest a more precocious sexual maturity.

Therefore, we wanted to know how Crocidura russula (Hermann, 1780 ), a species originating from Africa (Vogel \& Maddalena, in press), has adapted its sexual maturity to the climatic conditions of the temper-

1. This paper is part of a thesis, carried out at the University of Lausanne. The complete thesis is available at the Thesis Department of the Bibliotherque cantonale et universitaire, $\mathrm{CH}-1015$ Lausanne, Switzerland 
ate zone. The aim of this study was to determine whether this species has a precocious maturity, as the tropical members of its subfamily (Louch et al., 1979; Brooks et al., 1980; Jeanmaire-Besançon \& Vogel, in prep). or whether it has late maturity as observed in the sympatric members of the Soricinae, such as Sorex araneus.

\section{MATERIAL AND METHODS}

Between 1977 and 1980,540 specimens (256 우 et $\left.284 \delta^{\circ} \delta^{\circ}\right)$ were captured in western Switzerland, at altitudes ranging from $375 \mathrm{~m}$ to $1030 \mathrm{~m}$. The reproductive tracts were prepared for histological study (details in Besançon, 1984; Jeanmaire-Besançon, 1985). In males, maturity was determined according to several criteria: (1) green colour of testicles, (2) protuberance of seminal tubes; (3) developed interstitial tissue, (4) large quantities of spermatozoa in the testicles and the epididymides. Females were considered mature: (1) when pregnant $(n=63)$, (2) when pregnant and lactating $(n=47)$, (3) when lactating $(n=4),(4)$ in a postreproductive state $(n=7)$ and (5) if having aborted $(n=4)$. Achievement of sexual maturity in females could be objectively assessed only by gestation and lactation. Many inactive winterig females had a fully developed reproductive system and numerous large tertiary follicles (diameter $>300 \mu \mathrm{m}$ ) in their ovaries, showing that such histological characteristics cannot be considered as criteria of sexual activity.

The age of all individuals was estimated by measurement of tooth wear (details in Besançon, 1984; Jeanmaire-Besançon, 1986). Discriminant analysis separated the specimens into two groups: 366 young of the year (=group 1) and 174 overwintered individuals (=group 2). Shrews were grouped into seven classes of tooth wear by steps of $100 \mu \mathrm{m}$, after the mean height of the three molars of the right mandible (=factor A). Class $A_{1}$ grouped the youngest individuals (A $1200 \mu \mathrm{m}$ ). Class A7 grouped very old shrews with molar heights of less than $700 \mu \mathrm{m}$.

\section{RESULTS}

\subsection{Maturity and Age}

Among the 366 specimens born in the year of their capture (group $1), 35.5 \%$ were reproductive. Females $(43.8 \%)$ were sexually more precocious than the males $(28.6 \%)$. The youngest mature individuals were one to three months old (Table 1). After nine months of age, all the males had become mature. The oldest immature individuals were females, with an age. of twelve to fifteen months. They were certainly born in the spring and did not become mature before the following spring. The difference of age at sexual maturity, between the overwintered males and females, can be explained only in part by the earlier maturity of males in spring. 


\section{Table 1}

Proportion of reproductive males and females $(\% \mathrm{R})$, captured during the season of reproduction, and grouped according to their age.

\begin{tabular}{cccc}
\hline $\begin{array}{c}\text { Class of } \\
\text { tooth wear }\end{array}$ & Age (months) & n & \% R \\
\hline \multicolumn{4}{c}{ Males, group 1 } \\
A1 & $1.0-3.0$ & 27 & 26 \\
A2 & $3.1-6.1$ & 94 & 38 \\
A3 & $6.2-9.2$ & 21 & 52 \\
& Males, group 2 & \\
A3 & $6.2-9.2$ & 11 & 100 \\
A4 & $9.3-12.4$ & 21 & 100 \\
A5 & $12.5-15.5$ & 15 & 100 \\
A6 & $15.6-18.6$ & 9 & 100 \\
A7 & $>18.6$ & 1 & 100
\end{tabular}

Females, group 1

$\begin{array}{lrrr}\text { A1 } & 1.0-3.0 & 27 & 33 \\ \text { A2 } & 3.1-6.1 & 100 & 67 \\ \text { A3 } & 6.2-9.2 & 24 & 75\end{array}$

Females, group 2

$\begin{array}{rrrr}\text { A2 } & 3.1-6.1 & 1 & 100 \\ \text { A3 } & 6.2-9.2 & 16 & 87 \\ \text { A4 } & 9.3-12.4 & 21 & 86 \\ \text { A5 } & 12.5-15.5 & 15 & 92 \\ \text { A6 } & 15.6-18.6 & 5 & 100 \\ \text { A7 } & >18.6 & 2 & 100\end{array}$

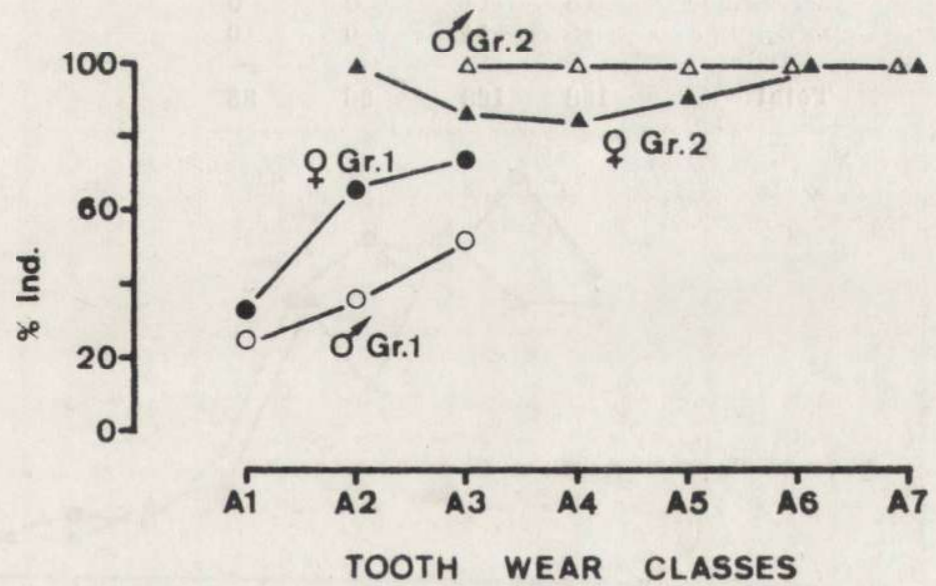

Fig. 1. Proportion of reproductive individuals (\% Ind.) captured during the reproductive season, for males and females, in groups 1 (Gr. 1) and 2 (Gr. 2) and for each class of tooth wear (A1 to A7). 


\subsection{Maturity and Season}

The percentage of juveniles of both sexes having reached sexual maturity within the year of birth was calculated for each month (Fig. 1; Table 2). High values were obtained in the spring and summer and a sudden decrease was observed in September (values significantly different from the August values, $t$-test, $p<0.05$ ). Values became very low in October and November. Males and females showed a different pattern: all young females were reproducing in May, whereas only two thirds of the males were sexually active (Fig. 1). A similar trend was observed in July when the proportion of mature females was almost double that of the males.

Table 2

Monthly numbers of males and females, belonging to groups 1 and 2 , for each month of the year.

\begin{tabular}{|c|c|c|c|c|}
\hline \multirow[t]{2}{*}{ Month } & \multicolumn{2}{|c|}{ Group 1} & \multicolumn{2}{|c|}{ Group 2} \\
\hline & $\widehat{\sigma} \sigma^{2}$ & 우우 & $\widehat{\partial \sigma}$ & 우 \\
\hline January & 0 & 0 & 11 & 11 \\
\hline February & 0 & 0 & 15 & 17 \\
\hline March & 0 & 0 & 20 & 25 \\
\hline April & 3 & 4 & 11 & 7 \\
\hline May & 9 & 8 & 9 & 6 \\
\hline June & 16 & 17 & 9 & 6 \\
\hline July & 33 & 23 & 5 & 3 \\
\hline August & 14 & 21 & 3 & 3 \\
\hline September & 68 & 49 & 3 & 10 \\
\hline October & 21 & 18 & 0 & 0 \\
\hline November & 16 & 14 & 0 & 0 \\
\hline December & 18 & 14 & 0 & 0 \\
\hline Total & 198 & 168 & 86 & 88 \\
\hline
\end{tabular}
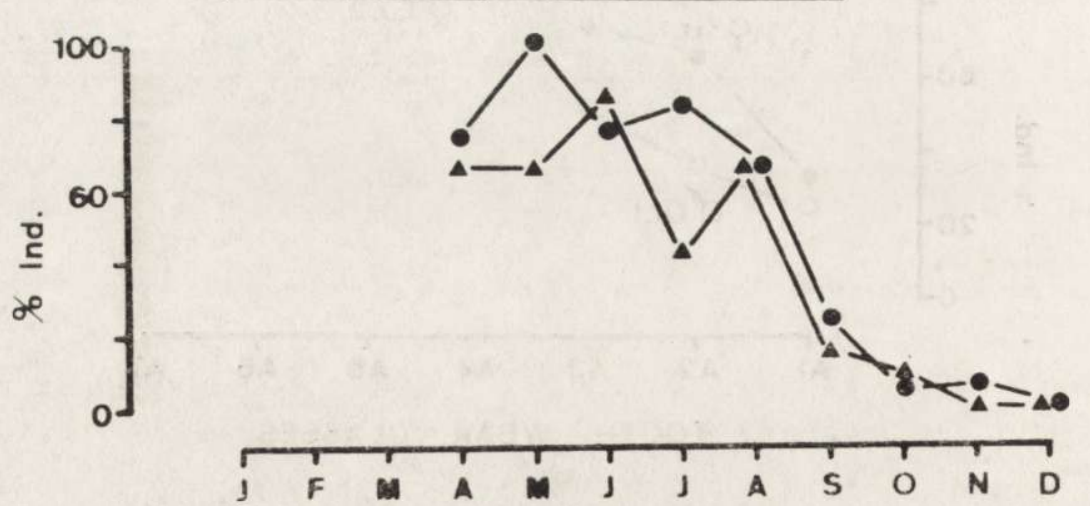

Fig. 2. Proportion of young males (triangles) and young females (circles) in reproduction or having reproduced ( $\%$ Ind.) for each month (averages of cumulated data of the four years 1977-1980). 
The respective proportions (averaged over the four years 1977-1980) of reproductive males and females of groups 1 and 2 are given for all the months in Fig. 3. The results show that reproduction is maintained well until April by overwintered shrews (group 2). Beginning with the months of May for females and June for males, reproductive activity remains important until late in the summer, due to juveniles (group 1).
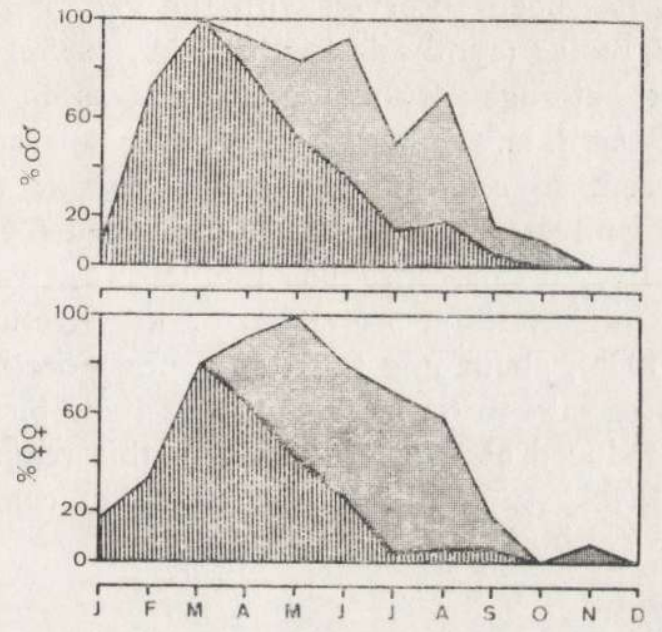

Fig. 3 Contribution to reproduction of males $(\% \hat{\delta})$ and females $(\% \circ O)$, active in groups 1 (shaded area) and 2 (striped area) (cumulated data from the four years 1977-1980).

\section{DISCUSSION}

The present study shows that Crocidura russula can reproduce very early, since $35.5 \%$ of the individuals achieved maturity during the year of their birth. So far, several contradictory results on the age at sexual maturity in temperate Crocidurinae have been published. In Crocidura russula, Bishop \& Delany (1963) reported a late maturity. On the contrary, Yalden et al. (1973) have already suspected that this species may achieve a precocious sexual maturity but these authors were unable to estimate the age of their specimens accurately. Ultimately, Lopez-Fuster et al. (1985) have shown that juveniles of the first litters can reproduce rapidly in spring (up to $70 \%$ of the young females are pregnant in May). The results of Rood (1965), on Crocidura suaveolens cassiteridum, are similar to ours: $24 \%$ of the young females reproduced.

Studies in marked populations of Crocidura russula have shown the variability of its sexual maturity. In a population followed by Besan- 
çon (1984), 14\% of the young females $(n=22)$ reproduced in 1978 and $0 \%$ in $1979(n=9)$. Genoud (1978) followed an urban population in western Switzerland during 20 months and was unable to capture any mature juvenile. However, in another study (over 21 months), he strongly suspected reproductive activity in a rural mountain habitat (Genoud \& Hausser, 1979). Age at sexual maturity may depend on the density of adult females, as has been observed with the very important studies on Clethrionomys glareolus (synthesis in Bujalska, 1985a, 1985b). However, the small size and heterogeneity of the study areas do not permit a statistical analysis of the data.

The high percentage of young Crocidura russula that are sexually mature stands in contrast to most values published for Soricinae (Table 3 ), which, generally, do not reproduce in their first calendar year. The situation may be different for Soricinae of the Arctic region. According to Schwarz (1962), about one third of young Sorex araneus and Sorex daphaenodon females bred in the year of their birth. $20 \%$ of young Sorex isodon reproduced also very quickly in this region (Kaikusalo, cited by Skarén, 1979). Apparently, this somewhat compensates for the

\section{Table 3}

Some data on the reproductive activity of young females in several species of Soricidae. $\mathrm{n}=$ sample size of young females, $\% \mathrm{R}=$ percent of active young females, $+=$ active young females observed, $-=$ no active young females observed.

\begin{tabular}{|c|c|c|c|}
\hline Species & $\mathrm{n}$ & $\% \mathrm{R}$ & Authors \\
\hline \multirow[t]{6}{*}{ Sorex araneus } & $?$ & - & Brambell (1935) \\
\hline & $?$ & - & Borowski \& Dehnel (1952) \\
\hline & 1708 & $0-2$ & Pucek (1960) \\
\hline & 255 & $3-29$ & Stein (1961) \\
\hline & 17 & 30 & Schwarz (1962) \\
\hline & $\begin{array}{l}200 \\
451\end{array}$ & $\begin{array}{l}5.5 \\
5\end{array}$ & $\begin{array}{l}\text { Skaren (1979) } \\
\text { Heikura (1984) }\end{array}$ \\
\hline \multirow[t]{2}{*}{ Sorex minutus } & $?$ & - & Brambell \& Hall (1937) \\
\hline & 302 & $4-10$ & Pucek (1960) \\
\hline \multirow{2}{*}{$\begin{array}{l}\text { Sorex daphaenodon } \\
\text { Sorex arcticus }\end{array}$} & 8 & 37 & Schwarz (1962) \\
\hline & $\stackrel{?}{39}$ & $\begin{array}{c}+ \\
5\end{array}$ & $\begin{array}{l}\text { Schwarz (1959) } \\
\text { Baird et al., (1983) }\end{array}$ \\
\hline \multirow[t]{2}{*}{ Sorex isodon } & 114 & 0.9 & Skarén (1979) \\
\hline & 139 & 20.1 & $\begin{array}{l}\text { Kaikusalo [cited by } \\
\text { Skarén (1979) }\end{array}$ \\
\hline Neomys fodiens & $?$ & - & Price (1953) \\
\hline \multirow[t]{2}{*}{ Crocidura russula } & $?$ & - & Bishop \& Delany (1963) \\
\hline & $?$ & + & $\begin{array}{l}\text { Yalden et al., (1973) } \\
\text { Lopez-Fuster et al., (1985) }\end{array}$ \\
\hline $\begin{array}{l}\text { Crocidura suaveolens } \\
\text { cassiteridum }\end{array}$ & $\begin{array}{l}99 \\
54\end{array}$ & $\begin{array}{l}33 \\
24\end{array}$ & $\begin{array}{l}\text { Lopez-Fuster et al., (1985) } \\
\text { Rood (1965) }\end{array}$ \\
\hline
\end{tabular}


shortness of the summer in the high Arctic, However, Baird et al. (1983) have not obtained similar results in the same region.

Precocious maturity in spring, reported for Neomys fodiens by $\mathrm{Ba}-$ zan (1956), seems an exception among the other Soricinae, living in a temperate climate. It is difficult to discuss the reproductive activity of young females in Neomys fodiens because data are too scanty.

With regard to our results, we can ask why Crocidura russula has not adapted a strategy similar to that of the sympatric Soricinae. Two explanations can be advanced. Firstly, the evolution of a strategy of the genus Crocidura, adopted in the tropical regions, could not be rapidly changed to another direction, even under the influence of the conditions of the temperate zone. Secondly, when Crocidura immigrated to Europe, Sorex already lived in the typical habitats of the temperate zone (Repenning, 1973). Competition prevented Crocidura from colonizing these habitats. This genus occupied the warm and dry habitats and the opportunistic species Crocidura russula settled near human dwellings, when climatic conditions were not favourable. It, therefore, avoided the habitats which would force it to modify its strategy of reproduction.

Acknowledgements: I would like to thank heartilly Professor Peter Vogel. His support, his help, and his very useful advice allowed me to complete this work. My gratitude is also extended to Mrs Josiane Hopfgartner and Mrs Anne-Marie Mehmeti for having helped me in the histological studies of the reproductive organs, and to $\mathrm{Mr}$ Roland. Gander for his preparation of the skulls of all my material. I thank Drs Michel Genoud and Roger Arditi for reading and commenting on one or more drafts of this paper.

\section{REFERENCES}

1. Baird D. D., Timm R. M. \& Nordquist G. E., 1983: Reproduction in the arctic shrew, Sorex arcticus. J. Mammalogy, 64: 298-301.

2. Bazan I., 1954: Untersuchungen über die Veränderlichkeit des Geschlechtsapparates und des Thymus der Wasserspitzmaus (Neomys fodiens fodiens Schreb.). Ann. Univ. Mariae Curie-Skłodowska, Sect. C, 9: 213-259.

3. Besançon F., 1984: Contribution à l'étude de la biologie et de la stratégie de reproduction de Crocidura russula (Soricidae, Insectivora) en zone tempérée. Doctorat thesis, University of Lausanne.

4. Bishop I. R. \& Delany M. J., 1963: Life histories of small mammals in the Channel Islands in 1960-61. Proc. zool. Soc., Lond., 141: 515-526.

5 Borowski S. \& Dehnel A., 1952: Angaben zur Biologie der Soricidae. Ann. Univ. Mariae Curie-Skłodowska. Sect. C, 7: 305-348.

6. Brambell F. W. R., 1935: Reproduction in the common shrew (Sorex araneus L.). Phil. Trans. Roy. Soc. Lond., Ser. B, 225: 1-62.

7. Brambell F. W. R. \& Hall K., 1937: Reproduction of the lesser shrew Sorex minutus L.). Proc. zool. Soc. Lond., 1936 (1937): 957-969.

8. Brooks J. E., Htun P. T., Walton D. W., Naing H. \& Tun M. M., 1980: The re- 
productive biology of Suncus murinus L. in Rangoon, Burma. Z. Säugetierkunde, 45: 12-22

9. Bujaiska G., 1985a: Fluctuations in an island bank vole population in the light of the study on its organisation. Acta theriol., 30: 3-49.

10. Bujalska G., 1985b: Regulation of female maturation in Clethrionomys species, with special reference to an island population of C. glareolus. Ann. Zool. Fennici, 22: 331-342.

11. Genoud M., 1978: Etude d'une population urbaine der musaraignes musettes (Crocidura russula Hermann, 1780). Bull. Soc. vaud. Sc. Nat., 74: 25-34.

12. Genoud M. \& Hausser J., 1979: Ecologie d'une population de Crocidura russula en milieu rural montagnard (Insectivora, Soricidae). Terre Vie, Rev. Ecol., 33: 539-554.

13. Heikura K., 1984: The population dynamics and the influence of winter on the common shrew (Sorex araneus L.). Spec. Pub. Carnegie Mus. Nat. Hist., 10: $343-361$.

14. Jeanmaire-Besançon F., 1985: Etude histologique de l'appareil génital de Crocidura russula (Insectivora: Soricidae). Rev. suisse Zool., 92: 659-673.

15. Jeanma:re-Besançon F., 1986: Estimation de l'âge et de la longévité chez Crocidura russula (Insectivora: Soricidae). Acta oecologica, Oecol. Applic., 7: $355-366$.

16. Lopez-Fuster M.J., Gosalbez J. \& Sans-Coma V., 1985: Uber die Fortpflanzung der Hausspitzmaus (Crocidura russula Hermann, 1780) im Ebro-Delta (Katalonien, Spanien). Z. Säugetierkunde, 50: 1-6.

17. Louch Ch. D., Ghosh A.K. \& Pal B.C., 1966: Seasonal changes in weight and reproductive activity of Suncus murinus in West Bengal, India. J. Mammalogy, 47: 73-78.

18. Price D., 1953: The reproductive cycle of the water shrew, Neomys fodiens bicolor Shaw. Proc. zool. Soc. Lond., 123: 599-621.

19. Pucek $Z$., 1960: Sexual maturation and variability of the reproductive system in young shrews (Sorex araneus L.) in the first calendar year of life. Acta theriol., 3: 269-296.

20. Repenning C.A., 1967: Subfamilies and genera of the Soricidae. Geol. Sur. Prof. Pap., 565: 1-74.

21. Rood J.P., 1965: Observations on population structure, reproduction and moult of the Scilly shrews. J. Mammalogy, 46: 426-432.

22. Schwarz S. S., 1959: Some biological peculiarities of Sorex articus Kerr. [In: "Materials to Fauna of North Ob region and its use". S. S. Schwarz ed.]. Trudy Selehard Station, 1: 255-271.

23. Schwarz S.S., 1962: Morphological and ecological characteristic of shrews at the most nothern limits of their range. Trudy Inst. Biol., Ural Branch of USSR Acad. Sci., 29: 45-51.

24. Skarén U., 1979: Variation, breeding and moulting in Sorex isodon Turov in Finland. Acta zool. Fenn., 159: 1-30.

25. Stein G.H.W., 1961: Beziehungen zwischen Bestandsdichte und Vermehrung bei der Waldspitzmaus Sorex araneus und weiteren Rotzahnspitzmäausen. Z. Säugetierkunde, 26: 13-28.

26. Vogel P., 1980: Metabolic levels and biological strategies in shrews. [In: "Comparative Physiology: Primitive Mammals". K. Schmidt-Nielsen, L. Bolis \& C.R. Taylor, eds.]. Cambridge University Press: 170-180. Cambridge.

27. Vogel P. \& Maddalena T., 1987: Note sur la répartition et la fréquence de la 
Musaraigne musette (Crocidura russula vebalensis) au Maroc. Mammalia, 51: 465-467.

28. Yalden D.W., Morris A. \& Harper J., 1973: Studies on the comparative ecology of some French mammals. Mammalia, 37: 257-276.

Received 1 October 1986, Accepted 21 December 1987.

Françoise JEANMAIRE-BESANÇON

DOJRZAŁOSC PECIOWA U CROCIDURA RUSSULA

(INSECTIVORA: SORICIDAE)

\section{Streszczenie}

W latach $1977-1980$ odłowiono $(\mathrm{n}=537)$ osobniki Crocidura russula (Hermann, 1780) w zachodniej Szwajcarii. Do określenia wieku dojrzałości płciowej wykorzystano histologiczne badania organów płciowych oraz stopień starcia zębów. $35 \%$ osobników rozmnażało się w roku urodzenia, przy czym samice wykazywały tendencję do wcześniejszego dojrzewania $(43.8 \%$ ) niż samce $(\mathbf{2 8 . 6 \% )}$ (Fig. 2). Młode urodzone na wiosnę osiągały dojrzałość płciową szybciej niż młode urodzone latem i jesienią. Osobniki, które przezimowały, zaczynały rozmnażać się na wiosnę. W lipcu większość rozmnażających się osobników stanowiły tegoroczne młode (Fig. 3). Tak wczesne dojrzewanie u Crocidura russula może być tlumaczone palaeotropikalnym pochodzeniem podrodziny Crocidurinae. 